\title{
The Changing of Laws Characteristics on Rights Determination of Children Born out of Wedlock on the Frame of Legal Pluralism in Indonesia
}

\author{
Hartini ${ }^{1}$, Mahaarum Kusuma Pertiwi, ${ }^{2}$ Destri Budi Nugraheni, ${ }^{3}$ \\ Khotibul Umam ${ }^{4}$ \\ ${ }^{1,3,4}$ (Faculty of Law University of Gadjah Mada, Indonesia) \\ ${ }^{2}$ (Norwegian Centre for Human Right The Faculty of Law University of Oslo, Norway)
}

\begin{abstract}
Children born out of wedlock always get discrimination in social, religion and law aspects in Indonesia. Almost all of the applicable legal systems in Indonesia, such as Adat law, civil law that is codified in the Civil Code, and Islamic law initially provide the regulation that marginalizes the rights of children born out of wedlock. When the international laws and policies are implemented and deal with regional, ethnic and religious entities, it has resulted mixed responses. This is reflected in Indonesian law especially regarding to the rights of children born out of wedlock after the enactment of the Law No. 23 of 2002 on Child Protection, in which it protects the children's rights in accordance with the basic principles of the Children Right Convention. This study intends to describe the law character which has plural system, in regulating the rights of children born out of wedlock after the enactment of the Law on Child Protection.
\end{abstract}

Keywords: Children born out of wedlock, Children's Right, Law Characteristics.

\section{Introduction}

By the enactment of the Law No. 1 of 1974 on Marriage (hereinafter referred to as the Law on Marriage), it does not mean that the issue of children born out of wedlock in Indonesia has been completed. [1] This law has mentioned that children born out of wedlock has only civil relations with her mother and her mother's family (Article 43 paragraph (1)) . Furthermore, the law states that the standing of the children will be further regulated in Government Regulation (Article 43 paragraph (2)). Unfortunately, until today, the government regulation that is mandated by the Law on Marriage has not been materialized yet. Needless to say, the regulation of the standing and the rights of children born out of wedlock returned to the previous regulations that regulated each population classes as applicable prior to the enactment of the Law on Marriage.[2] Thus, the regulations in the era of the Dutch colonial are reinforced, so the Adat law is applicable to indigenous communities, Civil Law derived from the Civil Code apply to those who subject to the Civil Code, particularly Indonesian citizen of Chinese and European descent, and Islamic law for the Muslim population of Indonesia.[3] The law submission of each different class also have implications on the judiciary, namely the use of Adat law and the Civil Code which becomes the absolute authority of the General Courts, while the use of Islamic law becomes the absolute authority of the Religious Courts. [4] The influence of globalization, that is indicated before, is not only limited on borderless state but also borderless law and it has made the values and principles of international law to penetrate other jurisdictions, including Indonesia.[5] When international laws and policies are implemented and exposed to the plural Indonesian legal entities, this study intends to reveal the responses of each legal entities that relate to the regulation of the rights of children born out of wedlock. A starting point to describe the responses of Indonesian legal entity is the era after the enactment of Law No. 23 of 2002 on Child Protection, in which it has introduced the importance of the application of child rights' principles in accordance with the Children Right Convention.

\section{Literature Review}

Since the beginning, the three law systems, namely, Adat law, civil law, and Islamic law have given regulations that marginalize the right of children born out of wedlock. Most of territories of indigenous peoples opinion that children born out of wedlock is deemed as the state which is not normal.The mother and the child are strongly denounced by the society. [6] Lesquilier in his writing categorizes extramarital sexual intercourse and the birth of children out of wedlock as a breach which destructs the emotional peace of community members. [7] They are seen proper to be given customary sanctions, such as being removed from the community and being derecognized as a member of the community. Social sanctions will also be attached to the child who would be born out of wedlock. In Java, a child born out of wedlock is called as an illegitimate child or Haram Child (Anak Haram), in Astra it is called an illegitimate child (Anak Haram), and in Lampung it is called 
"Kappang Child". [8] Although it is given that the main characteristic of Adat law is to put balance and harmony in the life of indigenous community, Adat law still provides means to avoid the customary sanctions, such as to force a woman to marry a man who impregnate her or other men. [9] It is similar to the child born out of wedlock. If the child wants to be a legitimate child and to be accepted as a member of community, the child is required to make a customary payment or donation to his/her particular community.

Civil law term is generally used to refer to the European Legal System derived from Roman. The intersection between Indonesian law and civil law is inseparable from the role of Dutch Colonial Government which introduced and enforced Burgerlijk Wetboek (Civil Code) in the colonial era.[10] After Indonesia gained its independence, the provisions in the Burgerlijk Wetboek which is transformed to be Indonesian civil law, is still enacted along there is no legislation which drew it. The Civil code, which is like other civil laws in general, has distinctive characters which are formal and relies on secular approach.[11] Strong encouragement from civil law to secularize the law is by separating law from religion. Basic ideology which is developed by the civil law system is that the law is created by the human intelligence without the requirements to refer to the God as the holy authority.[12] Law is formed to resolve the challenges of human life. It is not emphasised on the burden of human responsibility, but it is focussed on strengthening of rights. In terms of children born out of wedlock, the civil code creates an unique classification that children born out of wedlock are divided into two categories, namely children born out of wedlock in broad meaning and narrow sense. Children born out of wedlock in the broad sense is a child born due to sex out of marriage. While children born out of wedlock in the narrow sense is the children born out of legal marriage where the father and mother are not married with other parties. The children born out of wedlock in the broad sense do not have legal relationship with their father or mother, while the children born out of wedlock in the narrow sense have better position because they are possible to be legally recognized as heir (Article 280 of the Civil Code).

Islamic law is basically the law derived from religion of Islam. As a result, the law in the doctrine of Islam is understood as a means to serve the God, not the society. This principle is very predominant in Islamic law so that it is common that Islamic law is often labelled as a rigid law and it is hard to be reformed. Islamic law is not established to satisfy the human interest, but it is people who are expected to be submissive and obedient to the will of the God. It is similar to the Islamic family law which is substantively considered as the most sacred law. The starting point of the establishment of a family starts from a legal marriage under Islamic law. The sacredness of a marriage is manifested due to the unification of humanitarian aspects as well as aspects of worship. [13] A legal marriage will create further legal relationships, namely, the lineage relationship, trust relationship, and inheritance relationship. While, the marriage is a form of human servitude to carry out the orders of island.[14] Given the rigidity of Islamic law, it is logical that all legal events and consequences of adultery relationships are considered as meaningless things and treated differently. It is similar to the children born out of wedlock. They will be given negative stigma and treated differently because Islam strictly forbids adultery relationships.

Nowadays, the Indonesian society also gets a new challenge in the form of legal globalization, especially in terms of international pressure on human rights. Globalization is indicated not only as the borderless state, but also borderless laws.[15] The law of particular jurisdictions may penetrate into other jurisdictions. International and transnational laws can even be able to penetrate any local jurisdiction even into grassroots areas. While international laws and policies are implemented in and faced with regional entities, ethnic, and religious, according to Benda-Backman, “... the incoming law may be locally reproduced as a recognizably distinct and 'foreign' body of law, it may remain somewhat distinct but may be also become hybridized, creolised with legal forms or vernacularized, or it may be absorbed and becomes an inseparable part of the existing legal structure." [16]

\section{Methodology}

This research is a socio-legal study [17] which will connect practical issues in the determination and establishment of children born out of wedlock in human right perspectives. Since the socio-legal studies is an interdisciplinary research, it will employ social science approaches, including anthropology of laws (legal pluralism), sociology of law, Islamic law, Adat law, and the law of human rights. Sociological approaches or anthropology of law are used because from those approaches, the substance of law will be deeply examined. Through, textual study, provisions in regulations and policies can be critically analysed and it will deeply examine the meaning and implication of those provisions on certain groups, especially vulnerable groups [18] which in terms of this research, it is the children born out of wedlock. It also can be explained how provisions on laws are harmful or beneficial for particular groups and how it could happen. 


\section{Results And Discussions}

The designation of the laws in the beginning which starts from Adat law, civil law, and Islamic law is intentionally expressed to show the gradation of character and shape of the marginalization of the legal system from the low level to the high level. Adat law is considered as a flexible law because of the tradition of Adat law which is unwritten where it is easily developed according to legal interpretation which allows rules to be adjusted following the development and understanding of the society. Adat law in Indonesia is known as the law that is open for reform and provides positive appreciations for other legal traditions. It is proven by the acceptance of customary law when Islamic laws came to Indonesia. Islamic law is seen as the complement of customary law. Generally, customary law will be responsive to foreign laws by using particular criteria as the filter which the purpose of foreign law shall be to establish the peace and harmony in justice context with the same mission, namely advocating the goodness and forbid the evil, then the response of Adat law will be so positive. Therefore, in terms of the demand that the right of children born out of wedlock shall be advocated so that they are no longer in weak position, most likely Adat law will respond according to the community's sense on justice and propriety in certain situations. Thus, the legal settlement which will likely be emphasised is by basing the settlement on case by case (case law).

In discussing the response of civil law traditions as codified in the Civil Code with the inclusion of the values of international human rights into national law, it will result in several possibilities. Firstly, the process of acculturation of civil law, which is actually a colonial legacy, in the beginning of the independence of Indonesia, has been very massive, especially in substantive aspects of criminal law and several aspects in civil law. On the other hand, in terms of civil law aspect, especially in family law, the most parts have been largely dropped by the enactment of new legislations as the products of national legislation program. One of the legislations is the Law on Marriage. However, since the Law on Marriage is still considered incomplete and ambiguous by allowing the enforcement of the old rules, so that in terms of the rights of children born out of wedlock, the possibility of the application of ambivalent rules is also unavoidable. Secondly, the process of the acceptance of western legal traditions after the independence is by using the understanding of culture and traditions of the Indonesian law. It is similar to the formation of laws, the Indonesian legal culture is also employed as the philosophical foundation. In terms of that fact, the law on the right of children born out of wedlock will adjust to the Indonesian legal culture. Those possibilities indicate that there are unclear responses after the enactment of the Law on the Child Protection in terms of the rights of the children born out of wedlock based on the Civil Code. That lack of clarity is also influenced by the social background which supports that law. The groups of society which are subject to the Civil Code are mostly the Indonesian Citizen from Chinese and European Descent where when they apply for the recognition and endorsement of the children born out of wedlock, it is true that their status is children when they are in position with their parents. However, in terms of age, they cannot be categorized as a children because most of them are the old generation which is deemed as adults.

Islamic law, as explained before, is the law with rigid tradition with high sacred values, especially in terms of family law. Since the labels of Islamic law which is conservative, it would not be expected that Islamic law will accept new values of law which is deemed as the contrary of the predominant principles of Islamic law which have been followed and adhered by the majority of Muslims and have been internalized over centuries. In Indonesian context, although in the beginning, there is the intersection between Islamic law and foreign values as a contestations (competition on principles or interests), in the end, Islamic law tries revitalization which means doing several ways in terms of crucial issues (children born out of wedlock) by involving stakeholders in law aspects to find a method of legal finding and interpretation which accommodates the right of children born out of wedlock without avoiding Islamic law principles which is considered sacred. Authorities conduct a legal finding (Ijtihad) which is represented by the Indonesian Ulama Council (Majelis Ulama Indonesia/MUI) through the MUI Fatwa No. 11 of 2012 on the Status and Treatment of the Children Born out of Wedlock. Through this fatwa, Islamic scholars take the line that biological father can be punished by requiring him to meet the child's needs and provide access to his property by Wasiat Wajibah, not inheritance. This ijtihad is done to protect the children without the intention to legalize the lineage relationship between the biological father and the child born out of wedlock. Besides the legal finding made by the Islamic scholars (mufti), normatively the legal finding of Islamic law is also performed by the judges of the Religious Tribunal Court (qadi). While the first group conducts the legal finding and interpretation using fatwas, another group performs the legal finding and interpretation through court decisions on concrete cases. [19] [20] Judges in the Religious Court in Indonesia actually have produced several decisions which can be categorized as landmark decisions before the particular judicial review of the Constitutional Court on the Law on Marriage.[21] [22] The criteria of landmark decision is given to the court decisions on the amazing breakthroughs made by the judges in conducting legal findings and reasoning in the establishment of decisions. For Example, when a judge got a case of the petition of the recognition of the children born out of wedlock, the judge granted the petition and provided in decision that "the child is the biological child of the father. Such decision is legally written in the stipulation of religious court of Malang No. 415/Pdt.P/2010/PA.Kab.Mlg and the Stipulation of Religious Court No, 
416/Pdt.P/2010/PA.Kab.Mlg. [23] Although it looks simple, but the decision made by the judge means extraordinary because the judge tried to provide protections to the children born out of wedlock without violating the sacred values of Islamic law. Substantively, the child is actually the biological child of the father, but in the stipulation it seems that the judge did not violate Islamic laws because he did not legalize the lineage relationship between the biological child and the biological father.

\section{Conclussion}

When Adat law, Civil Law (which is codified in the Civil Code) and Islamic law are seen in the gradation level in marginalize the rights of children born out of wedlock, Islamic law gets the highest ranks as the most discriminatory law against the rights of children born out of wedlock, in accordance with the character of Islamic Law which is very rigid and it can be understood as the part of Islam's principles which contain the values of the sacredness that is hard to be reformed. In fact, after dealing with the values of international human rights law as introduced by the Law on Child Protection, although at first Islamic Law showed an attitude against the Western Law, in the further progress, Islamic law in Indonesia put itself as a highly responsive law in advocating the rights of children born out of wedlock. Through various efforts of revitalization, all efforts are deployed either through fatwas of Indonesian Ulama Council or Religious Court Decisions, which produce the decisions in the standard of landmark decision. At the same time, these kinds of things do not happen to the other legal system which is like the Adat laws and Civil Code including its implementation within the General Court.

\section{Acknowledgements}

We are very grateful to the Indonesian Directorate General of Higher Education through Institute of Research and Community Service (LPPM) University of Gadjah Mada for funding and supporting this research

\section{References}

[1] J. Satrio, The Family Law on the Status of Children in the Law, (Bandung:, Citra Aditya Bakti, 2005).

[2] D. Prinst, Indonesian Law on Children, (Bandung: Citra Aditya Bakti, 2003).

[3] [3] J. Girsang, The Treatment of the Case of Petition of Recognition od Children Born out of Wedlock in Practical Aspect, National Seminar on Status of Illigimate Children After The Judicial Review on Marriage Law Number 46/PUU-VIII/2010, Padjajaran University, Bandung 03 April 2012.

[4] M.D. Ali, Islamic Law: The Introduction of Law and the Structure of Islamic Law in Indonesia, (Jakarta: Raja Grafindo Persada, 1996).

[5] S. Irianto, et.al., The Movement of Law: the Study of Anthropology of Law, (Jakarta: Yayasan Obor Indonesia, 2009)

[6] F. Djamil, The Recognition of Illigimate Child, in C.T. Yanggo (Ed.), The Problem of Islamic Law Contemporary, (Jakarta: Pustaka Firdaus, 1999)

[7] R. Lukito, Secred and Secular Laws, (Jakarta: Alvabet, 2008 )

[8] B. Muhammad, Core Principles of Adat Law, (Jakarta: PT. Pradnya Paramita, 2006]. See also I. Sudiyat, Adat Law: Principles Sketch, (Yogyakarta: Liberty 2007)

[9] H. Hadikusuma, Introduction of Indonesian Adat Law, (Bandung: Mandar Maju, 2003)

[10] W. Prodjodikoro, Law Among Indonesian Group, (Bandung: PT. Bale, 1985)

[11] W.D. Putro, Critical-Philosopical Study on the Paradigm of Law Positivism, doctoral diss, University of Indonesia, Jakarta, 2011.

[12] M.D.Ali, 1996, Islamic Law: Introduction of Law and Structure of Indonesian Islamic Law ,(Jakarta: Raja Grafindo Persada, 1996)

[13] R. Lukito, Indonesian Legal Tradition, (Yogyakarta: Teras, 2008)

[14] A.A. Basyir, Islamic Marriage Law, (Yogyakarta: UII Press, 2000).

[15] Sulistyowati Irianto, The Movement of Law: A Study of Anthropology of Law, (Jakarta: Yayasan Obor Indonesia, 2009).

[16] Franz von Benda-Beckmann and Keebet von Benda-Beckman, Spatializing Law An Anthropological Geography of Law in Society, (England: Ashagate, 2009)

[17] R. Banaker and M. Travers, Theory and Methods in Socio Legal Research, (Oxford: Hart Publishing, 2005).

[18] S. Irianto dan Shidarta (eds.), , The Method of Law Research: Constelation and Reflection, (Jakarta: Yayasan Pustaka Obor Indonesia, 2011).

[19] J.N.D. Anderson, Islamic Law in the Modern World, (New York: New York University Press, 1959)..

[20] J M.A. Mudzhar, Fatwas of The Council of Indonesia Ulama: A Study of Islamic Legal Thought in Indonesia 1975-1988, (Jakarta: Indonesian-Netherlands Cooperation in Islamic Studies, 1993).

[21] Syafran Sofyan, Constitutional Court Decision on the Status of Children Born out of Wedlock, http://www.jimlyschool.com/read/analisis/256/putusan-mahkamah-konstitusi-tentang-status-anak-luar-kawin/. Accessed 27 Oktober 2013.

[22] Mahaarum Kusuma Pertiwi, Notes on Constitutional Court Decision No. 46/PUU-VIII/2010, Mimbar Hukum, Special Edition, November 2012, ISBN 0852-100X, ISSN 0852-100X,

[23] Hartini dan N. Darmini, "Prospect of Evidence Degree Reinterpretation and Reposition in Extra Marital Child Recognition Process After the Indonesian Constitutional Court Judicial Review on the National Marriage Act)," Research Report on Vocational School, (Yogyakarta: University of Gadjah Mada, 2012) 